\title{
Uranium(VI) Reduction and Removal by High Performing Purified Anaerobic Cultures from Mine Soil
}

\author{
Simphiwe Chabalala ${ }^{1}$ and Evans M. N. Chirwa ${ }^{1 *}$ \\ ${ }^{1}$ Water Utilization Division, Department of Chemical Engineering, University of Pretoria, \\ Pretoria, 0002, South Africa
}

Tel: 27 (12) 420 5894, Fax: 27 (12) 362 5089. Email: Evans.Chirwa@up.ac

\begin{abstract}
Biological uranium reduction was investigated using bacteria isolated from a uranium mine in Limpopo, South Africa. Background uranium concentration in soil from the mine was determined to be $168 \mathrm{mg} \mathrm{kg}^{-1}$ much higher than the typical background uranium concentration in natural soils $\left(0.30-11.7 \mathrm{mg} \mathrm{kg}^{-1}\right)$. Therefore it was expected that the bacteria isolated from the site were resistant to $\mathrm{U}(\mathrm{VI})$ toxicity. Preliminary studies using a non-purified consortium from the mine soil showed that $\mathrm{U}(\mathrm{VI})$ [uranyl(VI) dioxide, $\mathrm{UO}_{2}{ }^{2+}$ ] was reduced and re-oxidized intermittently due to the coexistence of $\mathrm{U}(\mathrm{VI})$ reducers and $\mathrm{U}(\mathrm{VI})$ oxidisers in the soil. Results from $\mathrm{U}(\mathrm{VI})$ reduction by individual species showed that the purified cultures of Pantoea $s p$, Pseudomonas sp. and Enterobacter sp. reduced U(VI) to $\mathrm{U}(\mathrm{IV})\left[\mathrm{U}(\mathrm{OH})_{4}(\mathrm{aq})\right]$ under pH 5 to 6. Klebsiella sp. had to be eliminated from the cultures since these contributed to the remobilisation of uranium to the hexavelant form. The initial reduction rate determined at $50 \%$ point in $30 \mathrm{mg} \mathrm{L}^{-1}$ batches was highest in Pseudomonas sp. at 30 $\mathrm{mg} \mathrm{L}^{-1}$, followed by Pantoea sp. Rapid reduction was observed in all cultures during the first $6 \mathrm{~h}$ of incubation with equilibrium conditions obtained only after incubation for $24 \mathrm{~h}$. Complete U(VI) reduction was observed at concentrations as high as $200 \mathrm{mg}$ $\mathrm{L}^{-1}$ and up to $88 \%$ removal after $24 \mathrm{~h}$ in batches with an initial added U(VI) concentration of $400 \mathrm{mg} \mathrm{L}^{-1}$.
\end{abstract}

Keywords: Uranium(VI) reduction, biosorption, indigenous culture, high-level waste bioremediation. 


\section{INTRODUCTION}

Uranium contamination of the environment from the mining and milling operations and nuclear waste disposal is a well-known global problem. Natural attenuation processes such as bacterial reductive/precipitation and immobilization of soluble uranium is gaining much interest (Dodge and Francis, 2008). For example, dissimilatory metal-reducing microorganisms have been investigated for their capability to selectively remove uranium from aqueous solutions (Lovley et al., 1992; Renshaw et al., 2005). These bacteria can use U(VI) as an electron acceptor thereby reducing soluble $\mathrm{U}(\mathrm{VI})$ to the precipitable tetravalent state [U(IV)] (Lovley et al., 1992; Lloyd and Renshaw, 2005; Lloyd et al., 2005).

Biological remediation processes offer a potentially environmental friendly and cost effective alternative for removing metal/radionuclide pollutants from dilute solutions where physico-chemical methods may not be feasible (Lovley et al., 1992). Biological methods are also considered flexible as they may be implemented either in situ or ex situ during the cleanup of contaminated sites. Such biological methods commonly use microbial consortia, consisting of several species of microorganisms in the form of bioflocs for removing/degrading the pollutants (Lloyd et al., 2005; Nancharaiah et al., 2006).

So far, there are four suggested mechanisms by which bacteria may immobilize the uranyl ion, namely; (a) biosorption, (b) bioaccumulation, (c) precipitation by reaction with inorganic ligands such as phosphate and (d) microbial reduction of soluble metal species to insoluble species (Nancharaiah et al., 2006). The

fourth process has been observed in Fe(III)-reducing and sulphate-reducing bacteria (Khijniak et al., 2005). Mesophilic representatives of the genera Geobacter, Shewanella, and Desulfotomaculum are also known to couple U(VI) reduction to 
growth, whereas $\mathrm{U}(\mathrm{VI})$ reduction in Desulfovibrio $s p$. has been shown to be mainly cometabolic with no energy derived from the reduction process (Khijniak et al., 2005).

A fundamental understanding of mechanisms of microbial transformations of uranium under a variety of environmental conditions will be valuable in developing appropriate remediation and waste management strategies as well as predicting the microbial impacts on the long-term stewardship of contaminated sites. The aim of this study is to utilise indigenous cultures of bacteria from the local environment to biologically reduce $\mathrm{U}(\mathrm{VI})$ to $\mathrm{U}(\mathrm{IV})$ and the objective was to investigate the ability of the three pure cultures; Pseudomonas sp., Enterobacter sp. and Pantoea sp. as well as mixed culture to reduce $\mathrm{U}(\mathrm{VI})$ at high concentrations.

\section{MATERIALS AND METHODS}

\subsection{Isolation and Maintenance of Indigenous Bacteria}

A mixed culture of bacteria was obtained by inoculating $200 \mathrm{~mL}$ of sterile basal mineral medium (BMM) amended with glucose as a sole supplied carbon source with $1 \mathrm{~g}$ of soil collected from an abandoned uranium mine (Phalaborwa, Limpopo). The BMM was prepared according to Roslev et al. (1998). Bacteria were maintained by monthly sub-culturing using nutrient agar and stored at $4{ }^{\circ} \mathrm{C}$.

\subsection{Purification of Indigenous Bacteria}

In preparation for the $16 \mathrm{~S}$ rRNA sequence identification, the bacterial cultures were purified by performing serial dilution to obtain individual colonies. The diluted culture samples from the $7^{\text {th }}$ to $10^{\text {th }}$ tube were then plated out onto nutrient agar plates and incubated for $24 \mathrm{~h}$ at $30{ }^{\circ} \mathrm{C}$. Six different morphologies were identified from the cultures, of which four were facultative anaerobes and two were aerobes. These were 
then individually streaked on nutrient agar plates followed by incubation at $30{ }^{\circ} \mathrm{C}$ for another $24 \mathrm{~h}$. This process was repeated twice in order to obtain the desired pure cultures.

\subsection{Culture Characterisation using 16S rRNA Gene}

A $16 \mathrm{~S}$ rDNA fingerprinting method was used to obtain DNA sequences of pure isolated cultures. Genomic DNA was extracted from the pure cultures using a DNeasy tissue kit (QIAGEN Ltd, West Sussex, UK) as per manufacturer's instructions. 16S rRNA genes of the isolates were then amplified by reverse transcriptase-polymerase chain reaction (RT-PCR) using primers pA and pH1. The primer pA corresponds to position 8-27 and primer pH1 corresponds to position 15411522 of the 16S gene (Coenye et al., 1999). The PCR products were then sent to Inqaba Biotech sequencing facility for sequencing where an internal primer $\mathrm{pD}$ was used. Primer $\mathrm{pD}$ corresponds to position 519-536 of the $16 \mathrm{~S}$ gene. The sequence relationships to known bacteria were determined by searching known sequences in GenBank using a basic BLAST search of the National Center for Biotechnology Information gene library.

\subsection{U(VI) Reduction experiments}

Bacteria grown overnight in nutrient broth was harvested by centrifugation at $6000 \mathrm{rpm}$ for $10 \mathrm{~min}$. The pellet was washed 3 times with $0.85 \% \mathrm{NaCl}$ solution and was re-suspended in $100 \mathrm{~mL}$ solution in $250 \mathrm{~mL}$ Erlenmeyer flasks for aerobic batch experiments or in $100 \mathrm{~mL}$ serum bottles for the anaerobic experiments. The average biomass concentration of $9.3 \mathrm{mg} \mathrm{mL} \mathrm{m}^{-1}$ was determined initially. A preliminary experiment using consortium cultures from soil showed U(IV) oxidation activities in

some of the species (data not shown) thus experiments were conducted with purified cultures to isolate $\mathrm{U}(\mathrm{VI})$ reducing species. Initial (added) U(VI) concentrations 
ranging from 30 to $400 \mathrm{mg} \mathrm{L}^{-1}$ were tested with pure cultures of bacteria. The experiments were conducted at $30{ }^{\circ} \mathrm{C}$ for a predetermined time interval (24-48 h) at 120 rpm on the orbital shaker (Labotec, Gauteng, South Africa). These were then purged with nitrogen for 5 min each. After reduction, the solution was centrifuged at $10000 \mathrm{rpm}$ for $10 \mathrm{~min}$. A syringe was used to draw samples at intervals up to $48 \mathrm{~h}$, followed by a uranium analysis in solution.

\subsection{Analytical methods}

A UV/vis spectrophotometer (WPA Lightwave II, Biochrom, Cambridge, England) was used to measure uranium in all samples. This instrument measures the level of hexavalent uranium (oxidized state of uranium - U(VI)) in the sample. The absorbance of each sample was measured using light with a wavelength of $651 \mathrm{~nm}$. Arsenazo III (Sigma-Aldrich, St. Louis, MO) (1,8-dihydroxynaphthalene-3,6disulphonic acid-2,7-bis[(azo-2)-phenylarsonic acid]), a non-specific chromogenic reagent, was selected as the complexing agent for facilitating uranium(VI) detection.

The accuracy and precision of the method was determined by measuring the concentration of standard uranium solutions in the range of 0.02 to $1 \mathrm{mg} \mathrm{L}^{-1}$ after appropriate dilution. The results showed that recovery of uranium was quantitative with good precision (92-100\%). The percentage deviation was found to be at a maximum $(0.4 \%)$ at dilution $0.5 \mathrm{mg} \mathrm{L}^{-1}$ whereas, the deviation decreased to zero when the concentration was decreased to $0.02 \mathrm{mg} \mathrm{L}^{-1}$. This method proved to be

reliable and accurate and is useful in routine analysis of uranium at $\mathrm{mg} \mathrm{L}^{-1}$ level in other solutions and materials. From literature, it was observed that anionic concentrations greater than 70 -fold and cationic concentrations greater than 50-fold excess over the uranium concentration decreased the normal absorbance of the uranium-arsenazo-III complex (Khan et al., 2006). The limit of detection for the 
UV/vis spectrophotometer was determined to be $0.02 \mathrm{mg} \mathrm{L}^{-1}$. The oxidized fraction of uranium was measured from a sample $(0.5 \mathrm{~mL})$ of the homogenous solution collected using a syringe and then centrifuged using a Minispin ${ }^{\circledR}$ Microcentrifuge (Eppendorf, Hamburg, Germany). The $0.5 \mathrm{~mL}$ sample was then diluted with $4.5 \mathrm{~mL}$ of BMM (1:10 dilution), mixed with $2 \mathrm{~mL}$ of complexing reagent and analyzed for U(VI) immediately at a wavelength of $651 \mathrm{~nm}$ against a reagent blank. Total uranium level in each sample (U(IV) and U(VI)) was determined by oxidizing an unfiltered sample with nitric acid prior to uranium measurement. This treatment converted U(IV) in the sample to U(VI) which was then measured colorimetrically as described above.

\section{RESULTS AND DISCUSSION}

\subsection{Microbial Analysis}

After purifying and sequencing the rRNA genes from the mine soil bacteria, a total of six bacterial species were identified. The rRNA sequences were isolated from bacteria with some resistance to U(VI) toxicity and were thus candidate species for U(VI) reduction. The results of the culture characterisation are shown in Table 1 .

Table 1. Characterisation of uranium-reducing facultative anaerobic bacteria isolated from the mine.

\begin{tabular}{|l|l|l|l|}
\hline $\begin{array}{l}\text { Sample } \\
\text { name }\end{array}$ & Blast result & $\begin{array}{l}\text { Max ID } \\
\mathbf{( \% )}\end{array}$ & Further down on list (same max ID) \\
\hline B1-1A & Pseudomonas stutzeri & 98 & Other Pseudomonas spp. \\
\hline B1-1B & Pantoea sp. & 98 & $\begin{array}{l}\text { Pantoea agglomerans, } \\
\text { Enterobacteriaceae }\end{array}$ \\
\hline A3-2 & $\begin{array}{l}\text { Klebsiella } \\
\text { pneumoniae }\end{array}$ & 98 & Other Klebsiella and uncultured \\
\hline A2-1 & Enterobacter sp. & 98 & Enterobacter cloacae and others \\
\hline A2-2 & Enterobacter sp. & 97 & Enterobacter cloacae and others \\
\hline
\end{tabular}


The facultative anaerobic bacteria from the mine soil showed a wide biodiversity of species. Pantoea agglomerans, a member of the family Enterobacteriaceae within the gamma subdivision of the Proteobacteria, has extensive metabolic capabilities under anaerobic conditions. It is a facultative anaerobic Fe(III)reducer capable of growing via the dissimilatory reduction of Fe(III), Mn(IV), and the toxic metal Cr(VI) (Tebo et al., 2000).

Bacillus species, an aerobic species is known to be resistant to U(VI) toxicity and removes soluble U(VI) by precipitation (Lovley et al., 2004). Other species observed are known to oxidise U(IV) to U(VI) and were not used for further experiments. An example is the anaerobic enzymatic U(IV) oxidation by Klebsiella sp. under near-neutral pH conditions. Specifically, U(IV) oxidising activity has been reported in pure cultures of nitrate grown - but not Fe(III)-grown - cells of Klebsiella sp. (Merroun and Selenska-Pobell, 2008).

So far, U(VI) reduction was observed only in anaerobic cultures as previously observed in studies conducted by Lovley and Phillips, 1992; Lloyd et al., 2005 and N’Guessan et al., 2008.

\section{2. $U(V I)$ reduction under varying initial concentrations}

Initial U(VI) concentrations were varied in batch studies under anaerobic conditions. Pseudomonas stutzeri, a denitrifying bacteria, showed a gradual increase in the rate of uranim- 6 removal at $50 \%$ of added $\mathrm{U}(\mathrm{VI})$ as the concentrations increased. In all the cultures tested, the maximum U(VI) activity occurred within the first $5 \mathrm{~h}$ of incubation (Figs. 1a-c). Very fast rates of U(VI) removal were observed, much faster than those normally encountered in literature where $1 \mathrm{mM}$ of $\mathrm{U}(\mathrm{VI})$ was removed only after $4 \mathrm{~h}$ when Desulfovibrio desulfuricans was suspended in bicarbonate buffer with lactate as the electron donor (Lovley and Phillips, 1992). 
Percentage recovery of total uranium was low for the higher concentrations (75-85, $\left.100 \mathrm{mg} \mathrm{L}^{-1}\right)$ and very high for the lowest concentration $\left(30 \mathrm{mg} \mathrm{L}^{-1}\right)$ as shown on Table 2. In Figure $1 \mathrm{a}-\mathrm{c}, \mathrm{U}(\mathrm{VI})$ is shown to be complete within the first $5 \mathrm{~h}$ in the $P$. stutzeri
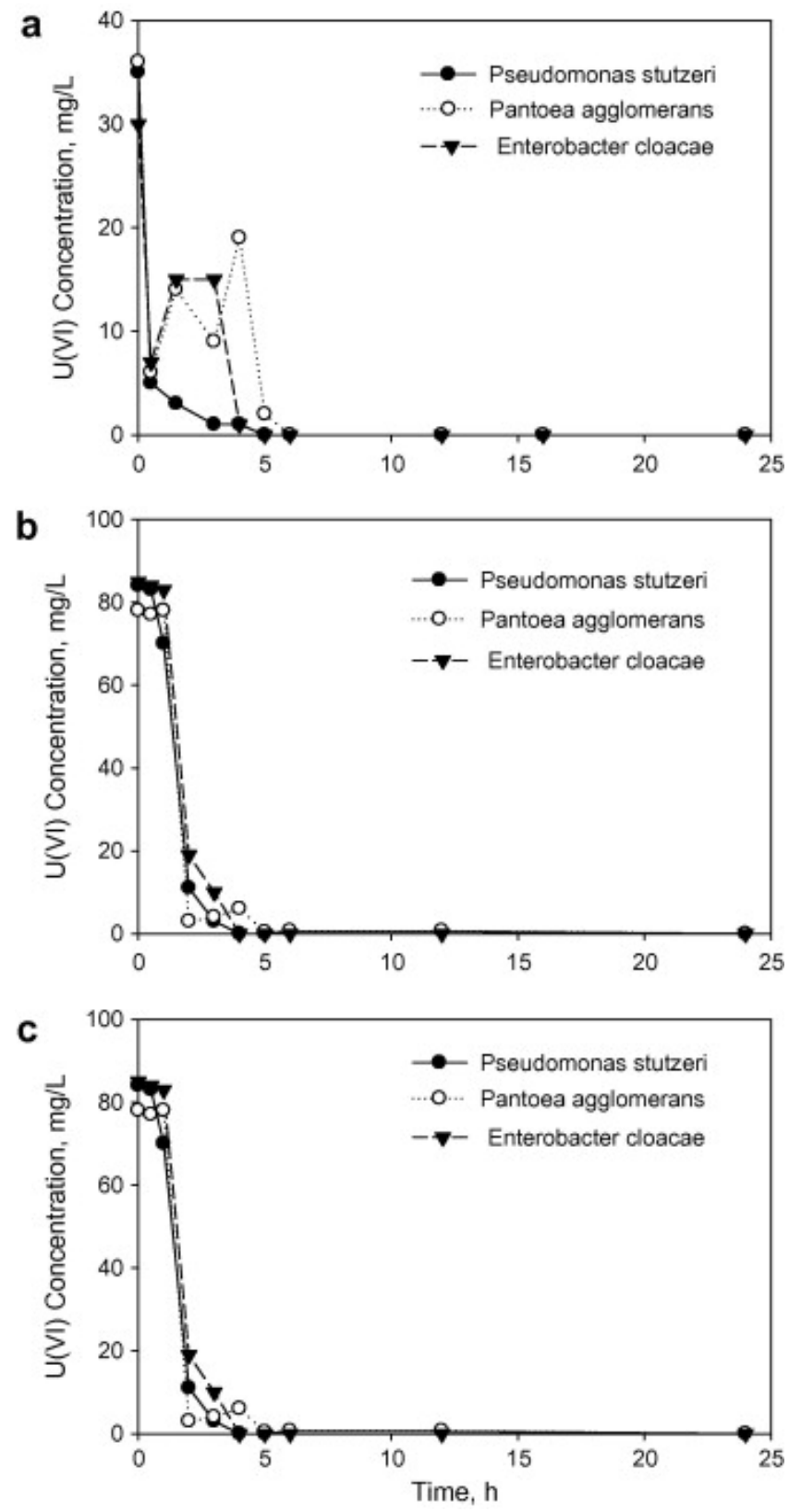

Figure 1. Uranium(VI) reduction for the three pure cultures of bacteria Pseudomonas stutzeri, Pantoea agglomerans and Enterobacter cloacae under an initial concentration of (a) $30 \mathrm{mg} \mathrm{L}^{-1}$, (b) $75-85 \mathrm{mg} \mathrm{L}^{-1}$, and (c) $100 \mathrm{mg} \mathrm{L}^{-1}$. 
Table 2. Kinetic data for varying concentrations of uranium U(VI).

\begin{tabular}{|c|c|c|c|c|}
\hline $\begin{array}{l}\text { Pure culture } \\
\text { species }\end{array}$ & $\begin{array}{l}\text { Initial } \\
\text { concentration } \\
\left(\mathrm{mg} \mathrm{L}^{-1}\right)\end{array}$ & $\begin{array}{l}\text { Removal rate at } \\
50 \%\left(\mathrm{mg} \mathrm{L}^{-1} \mathbf{h}^{-1}\right)\end{array}$ & $\begin{array}{l}\mathrm{U}(\mathrm{VI}) \\
\text { removal at } \\
24 \mathrm{~h}(\%)\end{array}$ & $\begin{array}{l}\text { Total U } \\
\text { recovery after } \\
24 \text { h (\%) }\end{array}$ \\
\hline \multirow[t]{5}{*}{$\begin{array}{l}\text { Pseudomonas } \\
\text { stutzeri }\end{array}$} & 30 & 17 & 100 & 63 \\
\hline & 75 & 20 & 100 & 29 \\
\hline & 100 & 50 & 99 & 32 \\
\hline & 200 & 33 & 81 & 87 \\
\hline & 400 & 80 & 87 & 84 \\
\hline \multirow[t]{5}{*}{ Pantoea sp. } & 30 & 16 & 100 & 50 \\
\hline & 75 & 20 & 100 & 27 \\
\hline & 100 & 50 & 99.5 & 36 \\
\hline & 200 & 57 & 83 & 98 \\
\hline & 400 & 95 & 86 & 71 \\
\hline \multirow[t]{5}{*}{$\begin{array}{l}\text { Enterobacter } \\
\text { sp. }\end{array}$} & 30 & 9 & 100 & 33 \\
\hline & 75 & 16 & 100 & 19 \\
\hline & 100 & 37 & 100 & 30 \\
\hline & 200 & 63 & 100 & 91 \\
\hline & 400 & 66 & 86 & 89 \\
\hline
\end{tabular}

batch. A significant rebound in $\mathrm{U}(\mathrm{VI})$ concentration was observed in the Pantoea sp. and Enterobacter sp. batches after the first hour. This was attributed to incomplete purification of the cultures resulting in the re-growth of uranium oxidising bacterial species. Similar patterns were observed in the other experiments at higher U(VI) concentration (Figs. 1c and Fig. 2). An average of $88 \%$ removal was observed by the different species at the high initial concentration of $400 \mathrm{mg} \mathrm{L}^{-1}$ (Fig. 2). 


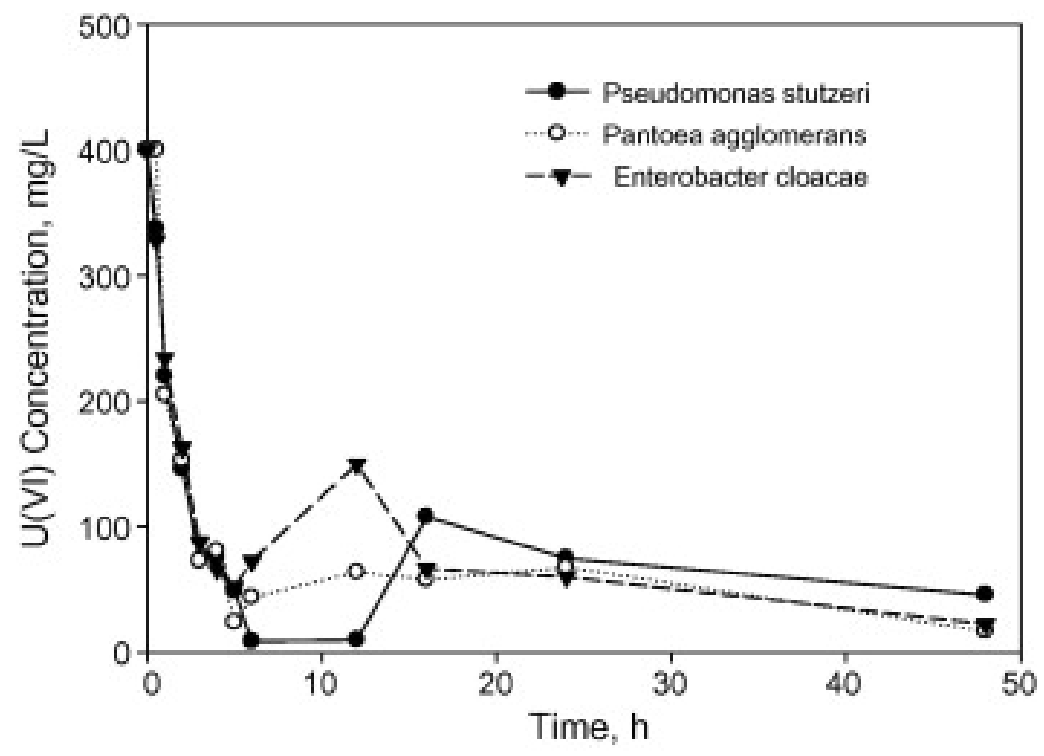

Figure 2. Uranium(VI) reduction for the three pure cultures of bacteria Pseudomonas stutzeri, Pantoea agglomerans and Enterobacter cloacae under an initial concentration of $400 \mathrm{mg} \mathrm{L}^{-1}$.

Pantoea sp. displayed a steady increase in the rate of removal at 50\% of added U(VI) as the concentration increased. This culture showed $100 \%$ removal at the end of $24 \mathrm{~h}$ for all three concentrations; 30, 75, $100 \mathrm{mg} \mathrm{L}^{-1}$ as shown on Table 2. Good recovery of total uranium - the sum of U(VI) and U(IV) concentration - was observed for the lowest concentration, $30 \mathrm{mg} \mathrm{L^{-1 }}$. This culture showed a lower percentage removal at the end of $24 \mathrm{~h}$ incubation for the highest concentration, $400 \mathrm{mg} \mathrm{L}^{-1}$, and recovery was high for both 200 and $400 \mathrm{mg} \mathrm{L}^{-1}$. The Enterobacter sp. proved to be the least efficient metal reducer among the cultures at the lower concentrations (30, 85 and $100 \mathrm{mg} \mathrm{L}^{-1}$ ) and had a low percentage recovery of total uranium. However, this species also proved to be the most efficient reducer at the highest concentrations (200 and $400 \mathrm{mg} \mathrm{L}^{-1}$ ) and a high percentage recovery of total uranium was observed at these concentrations at $50 \%$ of added U(VI). 
Overall, the best performance was observed in Enterobacter cloacae under all tested initial U(VI) concentrations when uranium removal was measured at the end of $24 \mathrm{~h}$. The cultures generally showed high resilience towards U(VI) toxicity and good performance even under high stress conditions.

\section{CONCLUSIONS}

The three pure cultures namely; Pantoea sp., Enterobacter sp. and Pseudomonas stutzeri removed U(VI) from solution under anaerobic conditions under $\mathrm{pH}$ conditions ranging from 5 to 6 . The removal rates in the three identified species were much higher than the values encountered in literature - with complete removal achieved in batches with initial concentrations up to $200 \mathrm{mg} \mathrm{L}^{-1}$ in less than five hours, and approximately $90 \%$ removal in batches with $400 \mathrm{mg} \mathrm{L}^{-1}$ initial concentration. The $\mathrm{U}(\mathrm{VI})$ reduction process was shown to be metabolically linked with higher removal rates observed under anaerobic conditions than under aerobic conditions. The lower recovered total uranium concentrations in some of the batches suggest the existence of additional mechanisms apart from the reduction-precipitation process by which the bacterial species removed uranium-6. The study highlights the importance of the detailed microbial analysis to optimise the performance of the culture by eliminating the U(IV) oxidising organisms from the consortium.

\section{ACKNOWLEDGMENTS}

The research was funded by the South African National Research Foundation (NRF) through the NRF Focus Areas Grant No. FA2006031900007 awarded to Prof. Evans M.N. Chirwa of the University of Pretoria. The student's master's programme was supported through a bursary from the South African Nuclear Human Asset \& Research Programme (SANHARP). 


\section{REFERENCES}

Coenye, T., Falsen, E., Vancanneyt, M., Hoste, B., Govan, J.R.W., Kersters, K., Vandamme, P., 1999. Classification of Alcaligenes faecalis-like isolates from the environment and human clinical samples as Ralstonia gilardii sp. nov. Int. J. Syst. Bacteriol. 49, 405-413.

Dodge, C.J., Francis, A.J., 2003. Structural characterization of a ternary Fe(III)U(VI)-citrate complex. Radiochim. Acta 91, 525-532.

Khan, M.H., Warwick, P., Evans, N., 2006. Spectrophotometric determination of uranium with arsenazo-III in perchloric acid. Chemosphere 63, 1165-1169.

Khijniak, T.V., Slobodkin, A.I., Coker, V., Renshaw, J.C., Livens, F.R., BonchOsmolovskaya, E.A., Birkeland, N.K., Medvedeva-Lyalikova, N.N., Lloyd, J.R., 2005. Reduction of uranium(VI) phosphate during growth of the thermophilic bacterium Thermoterrabacterium ferrireducens. Appl. Environ. Microb. 71, 64236426.

Lovley, D.R., Phillips, E.J., 1992. Reduction of uranium by Desulfovibrio desulfuricans. Appl. Environ. Microb. 58, 850-856.

Lovely, D.R., Shebolina, E.S, Sullivan, S.A., O’Neill, K.R, Nevin, K.P., 2004. Isolation, characterization, and U(VI)-reducing potential of a facultatively anaerobic, acid-resistant bacterium from low-pH, nitrate- and U(VI)-contaminated subsurface sediment and description of Salmonella subterranean sp. nov. Appl. Environ. Microb. 70, 2959-2965.

Lloyd, J.R., Anderson, R.T., Macaskie, L.E., 2005. Bioremediation of metals and radionuclides. In Atlas, R., Philp, J., (Eds.). Bioremediation: Applied Microbial 
Solutions to Real-World Environmental Cleanup. ASM Press, Washington, pp. 293317.

Lloyd J.R., Renshaw, J.C., 2005. Microbial Transformations of Radionuclides: Fundamental Mechanisms and Biogeochemical Implications. In Sigel, A., Sigel, H., Sigel, R.K.O., (Eds.). Metal Ions In Biological Systems: Biogeochemical Cycles of Elements. CRC, pp. 205-240.

Merroun, L.M., Selenska-Pobell, S., 2008. Bacterial interactions with uranium: An environmental perspective. J. Contam. Hydrol. 102, 285-295.

Nancharaiah, Y.V., Joshi, H.M., Mohan, T.V.K., Venugopalan, V.P., Narasimhan, S.V., 2006. Aerobic granular biomass: a novel biomaterial for efficient uranium removal. Curr. Sci. India 91, 503-509.

N’Guessan, A.L., Vrionis, H.A., Resch, C.T., Long, P.E., Lovley, D.R., 2008. Sustained removal of uranium from contaminated groundwater following stimulation of dissimilatory metal reduction. Environ. Sci. Technol. 42, 2999-3004.

Renshaw, J.C., Butchins, L.J.C., Livens, F.R., May, I., Charnock, J.M., Lloyd J.R., 2005. Bioreduction of uranium: environmental implications of a pentavalent intermediate. Environ. Sci. Technol. 39, 5657-5660.

Roslev, P., Madsen, P.L., Thyme, J.B., Henriksen, K. 1998. Degradation of phthalate and di-(2-ethylhexyl)phthalate by indigenous and inoculated micro-organisms in sludge-amended soil. Appl. Environ. Microb. 64, 4711-4719.

Tebo, B.M., Francis, C.A., Obraztsova, A.Y., 2000. Dissimilatory metal reduction by the facultative anaerobe Pantoea agglomerans SP1. Appl. Environ. Microb. 66, 543548. 